\title{
European Emission Allowance and the Equity Markets: Evidence from Further Trading Phases
}

\author{
Murad Harasheh ${ }^{\mathbf{1}}$ and Andrea Amaduzzi \\ Department of Business, Finance, \& Law \\ University of Milan-Bicocca, Italy
}

\begin{abstract}
Purpose - This study aims at investigating the value relevance of the European Emission Allowance (EUA) return and volatility on the equity value of the top listed European Power Generation Firms for the three trading phases of the European Emission Trading Scheme.

Design/methodology/approach - We employ the multifactor financial market model over the period 2005-2016 on daily basis for the return relevance relationship, whereas time series models such as ARMA and GARCH are applied on a weighted average portfolio of the sample firms to test serial correlation and volatility of returns.

Findings - Our findings are novel in which we show a positive and significant relevance of EUA return on equity return; however, a vanishing effect is seen as we move to further trading phases. Another remarkable finding is that the return relationship remains constant until a certain level in EUA price then inverts. Finally, we show that EUA is considered a systematic factor as firm and country specific features are not statistically significant.

Originality/Value - To our knowledge, this study would be the first to offer recent and comprehensive findings on the economic and financial implications of the European Emission Trading Scheme for the three trading phases. Additionally, the research offers time series robustness check besides the standard regression analysis and shows that there is an optimal EUA price that triggers polluters' decision on emission and generation.
\end{abstract}

JEL classification G12, G18, Q40, Q58

Keywords EU-Emission Trading Scheme, carbon emission allowance, power generation sector, trading phases, market model, time series models.

Paper type Research paper

\section{1- Introduction to the EU ETS}

The European Emissions Trading Scheme (EU-ETS) is a "cap and trade" system. It limits the greenhouse gas emissions (GHG) from installations and aircraft operators responsible for around $50 \%$ of EU GHG emissions. The system allows trading of emission allowances so that the total emissions of the installations and aircraft operators stay within the predetermined level at least-cost and at an economic efficient manner. The EU-ETS is considered the European Union milestone in abating emissions in its efforts to meet current and future targets. As the first and largest emissions

1 Corresponding author: Via Bicocca degli Arcimboldi, 8, 20126, Milan, Italy. Email: murad.harasheh@unimib.it. The authors are grateful to the editor, Niklas Wagner and an anonymous reviewer for their valuable comments to improve this manuscript. 
trading system for reducing GHG emissions, the EU-ETS covers more than 11,000 power stations and industrial plants in 31 countries, and flights between airports of participating countries (The European Commission, 2015).

The system was first introduced in 2005 as a prudent response to the Kyoto protocol ${ }^{2}$ that requires EU countries to reduce their GHG emissions on average by $8 \%$ until 2012 with 1990 reference level. Negotiations were held in the framework of the yearly UN Framework Convention on Climate Change (UNFCCC) Conferences on measures to be taken after the second commitment period ends in 2020. This resulted in the 2015 adoption of the Paris Agreement ${ }^{3}$ (also known as COP21), which is a separate instrument under the UNFCCC rather than an amendment of the Kyoto protocol. The system went through several changes since its commencement. The implementation of the system has been split into distinct trading periods over time, known as phases. The current phase of the EU ETS began in 2013 and will last until 2020.

The phases can be distinguished by certain cornerstone factors such as geographical coverage of the trading scheme, the sectors covered, the types of greenhouse gases captured, the cap allowed, and the eligible trading units. Moreover, in July 2015 the European Commission presented a legislative proposal on the revision of the EU-ETS for the fourth phase (2021-2030), in line with the EU's 2030 climate and energy policy framework. The proposal intends to reduce the EU-ETS emissions by $43 \%$ compared to 2005 level.

"Cap and trade" is the principle of the EU-ETS in which the total GHG emission for each phase by all industries included in the scheme is subject to a target at the EU level. Within this cap, companies receive or buy emission allowances that they can trade, if they wish to do so. In Phase 2 (2013-2020), the cap on emissions from power stations and other fixed installations is reduced by $1.74 \%$ every year. This means that in 2020, greenhouse gas emissions from these sectors will be $21 \%$ lower than in 2005. As for aviation industry, it joined the scheme in 2012 and a separate cap applies for 2013-2020 period, which has been set at a fixed level equal to $95 \%$ of the average annual level of emissions in the years 2004-2006. Allowances can be used only once. Companies have to surrender allowances for every ton of $\mathrm{CO} 2$ (or the equivalent amount of $\mathrm{N} 2 \mathrm{O}$ or PFCs) covered by the EU-ETS that they emitted in the previous year. Heavy fines are imposed if they do not deliver enough allowances to match their emissions (The European Commission, 2015).

As different from the first and the second trading phases, where free allocation was the default method of allowance allocation, since the beginning of the third trading phase in 2013, auctioning is the default method of allocating emission allowances. This means that businesses have to bid an increasing proportion of their allowances in the market. Auctioning is considered the most transparent method of allocating allowances and puts into practice the principle that the polluter should pay.

In sectors other than power generation, a transition to auctioning takes place progressively and the portion of allowances not allocated feely has to be auctioned. The portion of the auctioned allowances will increase by time, as the volume of allowances allocated for free decreases faster than the cap. In total, the Commission estimates that $57 \%$ of the total amount of allowances to be auctioned during 2013-2020, while the remaining part is available for free. The Commission's proposal for revision of the EU-ETS Directive foresees that the share of allowances to be auctioned will remain the same until 2020.

By capping whole GHG emissions from the major polluting sectors of the economy, the EU-ETS creates an incentive for companies to switch to cleaner technologies depending on the allowance price. The market price of allowances, sometimes known as the "carbon price", creates a greater incentive to change the production technology as it increases until the marginal cost of pulling becomes greater than the marginal cost of the cleaner technology.

\footnotetext{
2 Is an international treaty based on 1992 UN Framework Convention on Climate Change that was signed in Kyoto, Japan in 1997 and bringing the consensus to reduce greenhouse emissions as humankind made.

${ }^{3}$ Is an agreement within the UNFCCC dealing with greenhouse gas emissions mitigation, adaptation and finance starting in the year 2020. resulted in a common goal of keeping global warming within 2 degrees Celsius.
} 
In addition, revenues from the sale of 300 million are used to co-finance large-scale demonstration projects in two areas of low-carbon technologies: carbon capture and storage, and innovative renewable energy technologies. This funding program is known as NER300.

In this context, existing literature at the European level covers the possible implications of the scheme, mainly economic, financial and environmental implications. Studies, in this sense, included the impacts of the first trading phase (2005-2007) and part of the second phase (2008-2010) with a focus on the relationships between either the price/return, or volatility of emission trading allowance on equity valuation. However, there is a lack of current updated and comprehensive research on the linkage between financial markets and emission allowance. Hence, this research contributes to the limited and not up-to-date literature on the EU ETS finance by investigating the relationship between the EUA price changes and equity values of the main European listed power generation firms for the three trading phases which covers a short period post-COP21, which to our knowledge would be the first to offer recent and comprehensive findings on the economic and financial implications of the scheme. Additionally, the research offers time series robustness check besides the standard regression analysis and shows that there is an optimal EUA price, which triggers polluters' decision on emission and generation, and offers policy implications as considerations for the design of the next trading phase (2021-2030).

The rest of the paper is structured as follows, in section two we provide the related literature, section three is for data and sampling, methodology and model specifications are in section four, section five is dedicated for the portfolio approach, section six is for results and discussions, and finally, in section seven we show conclusions, implications and further research.

\section{2- Literature Review and Rationale}

Since its introduction in 2005, researchers have been investigating the multidimensional economic impacts of the EU-ETS on the pollution abatement cost, environmental innovations, and competiveness at sector and firm levels. Scholars argue that the overall allowance allocation in the first phase of the scheme has been qualified as generous (e.g. Ellerman and Buchner, 2008, Kettner et al., 2008). The possible implications of the scheme has brought into the arena discussions on potential losses in competitiveness for the companies covered by the scheme. Under the scheme, power sector is one of the most emitters of GHG and one of the early to be covered by the scheme to reach a decarbonized economy. According to Neuhoff et al. (2006), the sequential allocation process of emission allowance leads to distorted decisions in the power sector. Moreover, the electricity sector seems to be rather an exception as far as generous allowance allocation is concerned. Buchner et al. (2006) show that in 2005, power sector was the only sector to have a net short position; they also point that the absence of international competition and the assumption of comparably low emission abatement costs in electricity generation lead to a relatively stringent allowance allocation.

Past research has assessed the economic implications of the EU-ETS primarily in quantitative modelling contexts. Böhringer et al. (2005) show that the exclusive coverage of energy-intensive installations by the ETS implies that, in the absence of the Kyoto Protocol's project-based mechanisms, the remaining industries outside the ETS have to be regulated by complementary abatement policies in order to meet the national Kyoto targets. This implies that under a generous ETS cap, negative economic effects may be much larger for sectors outside than inside the ETS. Alexeeva-Talebi and Anger (2007) assessed both the macroeconomic and industry competitiveness effects of the EU ETS, they argue that the burden on ETS sectors might be minimized even under ambitious caps of the scheme if the project-based mechanisms of the Kyoto Protocol are available and if the EU-ETS is linked to other emerging trading systems outside Europe.

In this regard, there are three distinct streams of research that focus on different economic and financial aspects of the EU-ETS. One line of research evaluates the effect of movements in the price for carbon allowances on the returns of different sets of European electrical power companies. For example, Oberndorfer (2009) and Veith et al. (2009) use data from Phase I (2005 to 2007), Koch 
and Bassen (2013) extend their sample to 2010. These studies estimate the sensitivity of stock returns to changes in the price for carbon allowances, while also conditioning on other energy factors such as price changes in oil, gas, coal and electricity, whereas Oestriech and Tsiakas (2015) estimate the carbon premium in the stock price using factor model. Overall, this area of research establishes a positive relation between carbon price changes and equity returns of the European listed power generation companies.

A second line of research uses an event study methodology to study the effect of the drop in the price of the European Emission Allowance (EUA) in April 2006 on the stock returns of carbonintensive European companies. These studies include Bushnell et al. (2013) and Jong et at. (2014). They find that the drastic drop in the EUA price over a three-day window had a negative impact on the stock returns of carbon-intensive firms. This indicates that carbon regulation plays a significant role in determining the profits of dirty firms.

Finally, a third field of research is based on a simulation methodology that makes assumptions about the technology underlying coal-generated and gas-generated power. This approach is followed by, for example, Sijm et al. (2006) and Smale at al. (2006), who show that the introduction of the EU-ETS allows power companies to realize substantial windfall profits.

Given these lines of research, and the lack of extended research that includes the recent trading phases, the current study follows the first approach in which we investigate the effects of the EUA return and volatility behavior on the equity value of the main listed power generation companies in Europe. Power generation sector is said to have particular characteristics that makes the relationship between the EUA price and the equity value of a particular interest of research.

1- The sector enjoys a degree of immunity against international competition.

2- It also enjoys a significant degree of market concentration, (market power).

3- An energy-intensive industry.

4- Since the beginning of the third trading phase in 2013, energy generation sector is excluded from receiving free emission allowances.

Furthermore, According to Bain (1954), in investment-intensive industries, a significant level income from customers thanks to the barriers to entry generated, as capital intensity and economies of scale hamper the entrance to the market by others. Stigler and Friedland (1962) show that regulations were not able to break up monopoly and lower rents of US power producers, however, Clarke (1980) and Norton (1985) show that they even lowered the systematic risk of this industry. This demonstrates that windfall profits arise from the EUA price changes due to the industry structure and barriers to entry. Enjoying this degree of market power by companies under the EUETS leads to passing through all or part of the cost of the EUA especially during the phases where the emission allowances are freely allocated. The industry structure and the loose regulations during the first trading phase indicate possible free rents for firms under the ETS (Bovenberg et al., 2005). Consequently, if this thesis of the value relevance of the EUA and equity value is valid in informationally efficient financial markets, investors would positively consider the increasing carbon price and their equity holding which results in a favorable equity valuation.

Even though, the EU-ETS was created as a result of Kyoto protocol, its fourth trading phase 4 (from 2021-2030) is guided by Paris Agreement of 2015 to stay within the pre-determined GHG emission allowance and global warming limits. In this regard, few pioneering studies have been carried out to assess the economic and financial implications of COP21. Batten et al, (2018) show that oil investors can offset the oil price risk by holding a diversified global stock-oil portfolio with weights adjusted according to the implementation process of COP21. Murphy and McDonnel (2017) study the existence of carbon leakage in the co-firing biomass in Ireland and show that a significant

\footnotetext{
${ }^{4}$ To achieve the at least $40 \%$ EU target lower than 1990 level of emission, the sectors covered by the ETS have to reduce their emissions by 43\% compared to 2005.
} 
carbon leakage occurs due to relying on imported biomass that has higher GHG profile and that under COP21 scenarios to reduce the GHG emission from imported biomass by $24 \%$.

Obviously, there exist other broader related approaches to look at commodity and emission markets, which are beyond our specific scope. For example; the linkage between financial/economic development and GHG emission and how the development affects differently the environmental degradation in high, middle and low income countries (new evidence are found in Nasreen and Anwar 2015). Another issue is related to the financialization of commodity markets and its impact on commodity volatility behavior, this shows how the volatility behavior has changed due to the intersection between financial and commodity markets (Handika and Putra 2017, Basak and Pavlora 2016).

Based on the above screening of the state of art, the overall research objective is to examine the relationships between EUA price changes and the stock price behavior for the major power generation companies in selected EU countries for the three trading phases of the ETS. Hence we formulate the following questions:

1- Whether there is a significant relationship between EUA price changes and the equity value?

2- How this relationship might change with respect to various trading phases?

3- What are the implications of allowance variables on stock portfolio variance?

\section{3- Data and sampling}

To capture the three trading phases of the ETS, the related data was collected on daily basis from October 4, 2005 to December 31, 2016 making 2863 working days observations for the top 16 publicly traded power generation companies in Europe ${ }^{5}$, the result is 45808 firm-day observations, which corresponds to 45792 return observations ${ }^{6}$. The implications of COP21 on financial markets are partially included in the third trading phase (year 2016). The descriptions of the variables and the firms are available in Tables 1 and 2 respectively. In this study we consider the derivative (future) price as a better proxy of the EUA value for two reasons; first, investors seem to discount the future price of EUA rather than the spot price as shown by Oberndorfer (2009), second, to avoid bias and distortions since EUA spot price remained around zero from 16/2/2007 till the beginning of the $2^{\text {nd }}$ trading phase in January 2008. Data related to EUA price was collected from Sendco2. $\mathrm{com}^{7}$ for the $2^{\text {nd }}$ and the $3^{\text {rd }}$ trading phases, whereas data related to the $1^{\text {st }}$ phase was retrieved from a researcher who did a related work ${ }^{8}$.

\section{Insert Table 1 here}

Stock returns of selected firms whose business is affected by EU-ETS form the dependent variable of our analysis. The return series are analyzed respectively (pooled) within a panel data framework, as well as aggregated within an equally-weighted portfolio. For the purpose of the analysis, a Special attention is given to select firms that are considered top generators and have financial market (return) data available for the whole sample period. Firm-specific data related to primary energy input, percentage renewable, and carbon intensity were collected from PLATTS and Prospex research. To complete the model parameters, the return of the STOXX50 index is taken as a proxy for market return.

For the aim of assuring the absence of a unit root in the data series, a double check of the was performed using Augmented Dickey-Fuller (ADF) and the Phillip-Perron tests, in both tests we

\footnotetext{
${ }^{5}$ We select top 20 EU power generation firms according to PLATTS and Prospex research, we drop 4 firms for the lack of historical records or being publicly owned.

${ }^{6}$ Only 34 daily observations are missing for EDF Company since it went public 34 days after our starting point and the first available price data is on 21/11/2005.

${ }^{7}$ Is a specialized firm in EU-ETS platform and negotiation, was founded in 2004 and is a member of International Emission Trading Association IETA.

8 It was not easy to recover data for the 1st phase, so we thank Andrea Marcel Oestreich for providing us with the requested data.
} 
reject the null hypothesis of the existence of a unit root, and the data series can be used without further transformation.

\section{4- Methodology and Model Specifications}

Economic theory suggests that firm's activity in pollution certificates affect a firm's cost structure, a rising price of carbon alters the outlay for additional certificates, and the preferred input mix or the optimal output, hence decreases firm's income. Inherent to an emission trade is that the absolute effect of earnings is determined by the actual pollution caused by the production facilities and by the price quoted for the emission allowance (Zimmermann and Veith, 2007). Firms may also be able to simultaneously adjust the selling prices and pass on a share or all the cost the certificates. Capital markets provide insights how investors perceive this possibility. If the regulatory burden is expected to be born exclusively by the polluting firm, the relationship should be negative: following capital market theory, a rising price for the input factor emission allowance influences investors' expectations of the future profits and cash flows and hence leads to a decline in the share price. Additionally, this relationship can be a sector-specific or a country-specific factor that is influenced by the exposition to the international competition in a given sector and the degree of market concentration that guarantees firms in a specific sector a market power to pass-through higher share of allowance cost. Moreover, the type of allowance allocation in each trading phase is of a great importance for the determination of this relationship (free allocation vs. the paid auctioning of the EUA).

In order to test the hypotheses of this paper, a simple capital market model is utilized. The intuition is that investors in efficient capital markets consider any new public relevant information concerning listed firms which makes this information price-relevant (Ball and Brown, 1968; Fama, 1991). This allows using the capital markets as a gauge for the distributional effects on net profits.

In this context, we employ the Arbitrage Pricing Model (APT-style market model) to capture the incremental economic implications of the regulatory changes of the EU-ETS. Returns generated from EUA price changes might indicate a change in wealth of firms covered by the scheme. In this sense, if capital markets are efficient enough to discount the effects of the regulatory changes as a value a relevant factor, we expect to find significant EUA coefficients in the model. On the other hand, we expect to find negative EUA coefficients with equity values when power firms are not able to discharge additional allowance cost to final customers. In line with these assumptions and following the work of Oberndorfer (2009), Veith, etal. (2009) and Koch and Bassen (2013), the stock return is estimated using the following market model,

$R_{i t}=\alpha+\beta_{1} R M_{t}+\beta_{2} E U A_{t}+\varepsilon_{t}$

Where;

$\alpha$ is the intercept, which represents the return on non-market portfolio;

$\beta_{1} \& \beta_{2}$ are the coefficients of market return and allowance return respectively;

$R_{i t}$ is the logged daily return on the common equity of firm $i^{9}$ at time $t$;

$R M_{t}$ is the logged daily return on the market portfolio represented by Stoxx 50;

$E U A_{t}$ is logged daily return on the European emission allowances future price;

$\varepsilon_{t}$ : The disturbance term

In Eq. (1), the coefficients $\beta_{1}$ and $\beta_{2}$ capture the market risk as well as the incremental effect for negotiating emission allowance. Similar to a single factor beta, the EUA coefficient measures the change in returns on common stock of a firm for each $1 \%$ change in returns the EUA.

${ }^{9}$ The return equation utilized is Return $_{i t}=\log \left(\frac{P_{i t}}{P_{i, t-1}}\right)$ 
To capture the firm-specific and country-specific features, we run the model on the panel dataset by adding country and firm dummies as well as other firm specific factors, the specific factors are the following;

- Firm fixed effect

- Country fixed effect

- PEI is Primary energy input fixed effect

- \%RES is the logged percentage of renewable share in firm's generation mix

- MoreRes is a binary variable for firm with \%RES more than the average

- $\mathrm{CI}$ is the carbon intensity

- LessCI is a binary variable for firms with CI less than the median.

In the same regard, variations of the APT model are applied depending on the diagnostic statistics of the series; a pooled OLS is applied when the series are free of serial correlation and hetroskedasticity, Prais regression with generalized least squared (GLS) when the series exhibit a serial correlation and the robust regression in case hetroskedasticity exists. Finally, we also verify panel analysis utilizing fixed effect and random effect regressions.

\section{5- Portfolio Approach}

On the other hand, to avoid firm or country specific effects' bias, we construct an equally weighted portfolio of the sample firms for the whole period, and we run the model on the whole dataset as well as on each trading phase. For being non-exhaustive in the robustness analysis and in addition to the multi-factor model, we apply the following tests for the portfolio section on aggregate terms without breaking down into trading phases or going further into panels.

1- Multivariate time series checks: time series models tend to predict the current value from its previous values. The rationale for using them is mainly to overcome some assumptions of the standard linear regression. Since our dataset is considered a time-series (with 2862 daily portfolio observations) and the existence of a unit root is previously rejected; we apply the following multivariate time series models to see the impact of emission allowance variables and market variables on portfolio return and variance.

a) Return relationship: Autoregression Moving Averages ARMA (1,1) model is represented in the following form:

$R_{t}=\alpha+\beta_{1} R_{t-1}+\gamma_{1} \omega_{t-1}+\omega_{t}+\beta_{2} \mathrm{EUA}+\beta_{3} \mathrm{RM}$

Where $R_{t}$ is the portfolio return, $R_{t-1}$ is the first order autoregression term, $\omega_{t}$ is the residuals term and $\omega_{t-1}$ is the first order moving average term of residuals. In ARMA notion, the portfolio return is explained by previous returns and previous errors.

b) Volatility relationship: not only appreciations and depreciations of the EUA price may matter for the equity value of electricity firm. Changes the in volatility in the EUA market should adjust the expectations for future cash flows of the corporations covered. A possible model to test this thesis is by using the Generalized Autoregressive Conditional Heteroskedasticity (GARCH). Models of the GARCH-class (Bollerslev, 1986) are considered appropriate models for the analysis of high-frequent time series in financial markets by addressing the phenomenon of volatility clustering. The model uses values of the past squared observations and past variances to model the variance at time $t$

$$
\begin{aligned}
\sigma_{t}^{2}=\alpha+\alpha_{1} \mathrm{a}_{t}^{2}+\beta_{1} \sigma_{t-1}^{2} & +\beta_{2} \mathrm{EUA} \\
& +\beta_{3} \mathrm{EUA}_{\mathrm{std}} \\
& +\beta_{4} \mathrm{RM}_{\mathrm{std}}
\end{aligned}
$$


where $\sigma_{t}^{2}$ is the variance of the portfolio returns ${ }^{10}, a_{t}^{2}$ is squared of residuals ${ }^{11}, \sigma_{t-1}^{2}$ is the first order autoregression term of portfolio variance, and $\mathrm{EUA}_{\text {std }}, \mathrm{RM}_{\mathrm{std}}$ are the standard deviations of allowance returns and Stoxx 50 returns respectively. In the GARCH notation, stock price conditional variance is explained by the previous period's variance plus an additional factor related to the volatility of the ETS allowance price.

2. Quadratic (non-linearity) test to check whether the relationship between firms' portfolio return and allowance return remains constant or inverts at a certain point in emission price? This is to verify whether there exists an optimal price of the EUA that might invert the behavior of power generators?.

$R_{t}=\alpha+\beta_{1} R M_{t}+\beta_{2} E U A_{t}+\beta_{3} E U A_{t}^{2}+\varepsilon_{t}$

Where $E U A_{t}^{2}$ is the squared return of emission allowance return.

\section{Results and Discussions}

\subsection{Preliminary results}

Table 2 shows the selected 16 top power generators in Europe, they belong to 10 countries, it also shows that average daily return for each firm for the three respective trading phases, we can notice a remarkable drop in firms' return after the first phase which confirms how generous allowance allocation was during the first phase. In the same Table we show the revenues and the energy activity on 2015, it shows how power players in Europe are being affected by more stringent regulatory environment; for example in 2015, eleven firms out of top 20 reported net loss equal to 13 billion euro compared to 10 billion euro for the other nine firms, E.ON and ENGIE together reported a loss about 11.5 billion euro. The majority of firms use fossil fuel as a primary energy input, the average share of renewable is $26 \%$, and there are only six firms above the average. Whereas, the median for carbon intensity is $391 \mathrm{~g} / \mathrm{kwh}$ and firms are analogously around the median.

\section{Insert Table 2 here}

Moreover, Tables 3 and 4 show the descriptive statistics for the panel and the portfolio separately, both Tables show results for the three phases as one set and for each respective phase. Table 3 demonstrates how the emission allowance is more volatile and more profitable than both the market and the stock, which is consistent with risk-return theory. We can additionally notice that the allowance volatility is growing by moving to further trading phases. Figures in Table 3 confirm the superiority of emission allowance in terms of volatility and return, we further add Phillip-Perron and Augmented Dickey-Fuller as tests of a unit root, and both reject the existence of a unit root in the series and we conclude that the logged daily return of emission allowance, the market, and the portfolio can be used at their levels without additional transformations.

\section{Insert Tables 3 \& 4 here}

\subsection{Panel Results}

In this subsection, we present the findings of the panel analysis; it contains the analysis for the whole dataset and for each single trading phase. In Table 5 we present the results of the complete series including the three phases (aggregate), Model 1 with the simple pooled OLS (with no firm or country effect) shows that EUA coefficient is positively and statistically significant in explaining equity returns with beta $=0.016$. Models from 2 to 7 utilize pooled OLS with firm and country

\footnotetext{
${ }^{10}$ Weighted average of the stock return of the 16 firms

${ }^{11} a_{t}=\sigma_{t} \times \varepsilon_{t}$
} 
effects and it is noticeable that neither $\mathrm{R}^{2}$ nor Root MSE improved and the coefficients of the fixed features are insignificant, this implies that the emission allowance and equity market relationship is homogeneous and systematic among all firms with no firm or country effects. Model 9 and 10 are dedicated to the fixed and random effect models that show no improvement in EUA and RM coefficients, which makes the simple pooled OLS an appropriate model for such a panel ${ }^{12}$.

\section{Insert Table 5 here}

In Tables 6, 7 and 8, we breakdown the panel analysis by each single trading phase. Findings of phase one are shown in Table 7, EUA coefficient is 0.024 which is the highest and more statistically significant in explaining equity behavior with respect to EUA coefficients in phase II and phase III. In this sense, the coefficients of EUA and RM obtained for phase I are consistent with the very few studies for the same period such as Veith et al. (2009) and Oberndorfer (2008). The findings of phase I demonstrate how the first trading phase was a pilot with low restrictions on allowance allocation and trading - which is referred to the generous allocation in phase I -. In this regards, the findings imply that investors in financial markets look at power firms with market power that they are able not only to pass to their clients the regulatory costs but they also they can achieve windfall profits. Regarding the findings of phase II in Table 7, even though EUA coefficient lost in magnitude; it is still positive and significant in the valuation of equity price by financial markets, the coefficient dropped from 0.024 to 0.011 but significant at $5 \%$ level while the coefficient in phase I is significant at $1 \%$ level. These findings, in fact, demonstrate the economic impacts on power generators as due to a more stringent phase in terms of allocation, trading, and emission caps. In the same vein, in Table 8 we present the results of phase III, EUA coefficient of 0.017 significant at $5 \%$ level is lower than the coefficient of the first phase, which shows that phase III is also considered stringent with respect to the first phase ${ }^{13}$. Furthermore, we note here that in the results of the three phases, models are tested with firm and country specific factors in addition to fixed and random effect models, none of these models show any improved significance over the pooled OLS, this confirms that in all trading phases, firm and country specific effects are not significant in adding any value relevance and that the EUA and equity value relationship is systematic among firms and countries without proof of any grouping or clustering.

\section{Insert Tables 6, $7 \& 8$ here}

\subsection{Portfolio Results}

Another approach of analysis is performed based on an equally weighted portfolio composed of the sample companies. The purpose of this approach is to eliminate any specific factors and to melt down all companies as one set, and to offer more robustness checks since we added two main additional tests; the linearity test and the time series tests of ARMA and GARCH ${ }^{14}$.

In Table 9, we present the results of the return relationship of the portfolio using the market model. Consistent with the panel results, the aggregate and the separate phases show that the relationship between EUA and portfolio value is persistent in the three phases, however, it is more significant and profound in phase one. Moreover, checking for diagnostic statistics and to get more robust coefficients, a robust regression is used where heteroscedasticity is verified in the series, whereas, Prais regression is used where serial correlation is detected in the series.

\footnotetext{
${ }^{12}$ Additional diagnostic tests are implemented such as Hausman test for fixed Vs random effect, and the Breusch-Pagan Lagrange Multiplier, both tests result in considering pooled OLS as an appropriate model.

${ }^{13}$ In the $3^{\text {rd }}$ phase 2013-2020, emission cap for power generation is reduced by $1.74 \%$ each year and no free allowances.

14 Linearity and time series tests are applied to the portfolio on aggregate level, means the whole time period of 2862 daily observations.
} 


\section{Insert Table 9 here}

Moreover, in Table 10, we shed the light on the additional tests. In model 1, we test the linearity relationship and we show that the $\mathrm{EUA}^{2}$ is statistically relevant in the portfolio valuation with a negative sign, which indicates that the relationship between EUA and equity value inverts at a certain point in EUA price. This seems plausible because companies continue to buy and profit from the allowance as long as carbon price is low and firms can pass on this cost to final customer, however, when EUA price exceeds the optimal level viewed by firms, it becomes more economical to adapt cleaner generation technologies and stop or reduce buying the allowance. In model 2, we demonstrate the market model with ARMA $(1,1)$ order since the series exhibit a degree of serial correlation, it shows that current return is strongly predicted by the previous return and the previous residuals.

\section{Insert Table 10 here}

Finally, in the last section of Table 10 we present the volatility relationship utilizing GARCH $(1,1)$ model. Model 3 with no explanatory variables shows that current portfolio volatility is influenced by its first order lag variance, and its squared residuals. In model 4, EUA demonstrate to have a significance on the portfolio variance. However, in model 5 , the volatility of allowance return has no significance on the portfolio volatility, whereas, market volatility is strongly and positively correlated to the portfolio variance.

\section{Conclusions and implications}

This is considered a unique study that presents recent findings related to the economic evaluation of the European Emission Trading Scheme since its inception in 2005 until 2016 (three trading phases included). In this research, we try to establish value relationships between emission allowance and equity value of the top European Power Generation Listed Companies, and we show that the relationship changes by time as each trading phase enters into force. The analysis is performed under four main approaches; return and volatility models, panel and portfolio approaches, OLS and time series models, and on aggregate and for each single-phase perspective.

Regarding the findings, and consistent with the previous studies, we find positive and significant coefficients related to EUA price changes in equity valuation in the early trading phases of the ETS; however, a vanishing effect is found as we move to further trading phases as allowances are not anymore allocated free. These results are persistent in both panel and portfolio analyses. The findings indicate that EU power generators are losing power in the emission market as the emission system advances to further trading phases. Furthermore, we show that the relationship between equity return and allowance return is a systematic feature that applies for all firms, countries, fossil and non-fossil generators, renewable share, and the varying carbon intensive generators with no statistical difference among all of these clusters or fixed effects.

The analysis of return time series model ARMA confirm the results of the standard least square regressions in which both market return and emission allowance return are considered important predictors of portfolio returns. Furthermore, we show that previous portfolio return and previous errors are able to significantly predict current portfolio return. On the other hand, the variance GARCH model shows that EUA return variance is not statistically significant in explaining (predicting) portfolio variance, however, market variance and EUA return can significantly explain portfolio variance.

Finally, in the quadratic test, we show that the squared return of EUA $\left(E U A_{t}^{2}\right)$ is significantly negatively correlated with portfolio return which shows that the relationship between equity return and EUA return does not remain constant but inverts at a certain level in EUA price. This result in fact proves the cost-benefit decision making by power generators in which generators continue to use (or buy) emission allowance, and pollute, as long as the allowance price is low but up to a 
certain level, however, when the emission price exceeds that level it becomes not anymore economical to buy-and-pollute and generators are forced to change to a more efficient or cleaner generation technology.

In conclusion, although phases II and III are considered more stringent from a regulatory point of view in terms in terms of the share of free allocations, the trading mechanism, and the emission limits, power generation companies still enjoy a degree of market power indicated by the positive a significant association between EUA and equity value, Investors still believe that their energy companies can make windfall profits and can overcome regulatory stringency and that emission regulations still play a significant role in determining the profits of dirty firms. Moreover, albeit the last year of the study (2016) is considered a post-COP21 on climate risk mitigation, Kyoto standards still govern until 2020, that's why we don't notice remarkable changes in the results in which carbon prices did not adjust enough to force power generators to adapt their technologies.

At policy level, these findings signal policy makers for an appropriate design of the future trading phases in which they achieve the balance between public interests, as climate risk mitigation by reducing emissions, and the private interests of the market players to support innovative changes.

\section{Further research}

Notwithstanding this research includes the three trading phases, the third phase has not yet concluded - expires in 2020 and a forth phase begins -, other research is needed regarding different samples and different approaches. It is essential to extend the dataset until recent dates and include other groups of firms such as a group of industrial firms and a group of clean firms out of the ETS to compare the results. More recent causality studies are needed to verify the economics and the environmental effects of the ETS during the three phases. Moreover, research related to the investment in cleaner technologies by firms is needed to see the linkage between the emission scheme and clean investment decision-making post COP21.

\section{Bibliography}

Alexeeva-Talebi, V. and Anger, N. (2007), "Developing supra-European emissions trading schemes: An efficiency and international trade analysis", ZEW Discussion Paper No. 07-038, Mannheim.

Bain, J.S. (1954), "Economies of scale, concentration, and the condition of entry in twenty manufacturing industries", American Economic Review, Vol. 44, pp. 15-39.

Ball, R. and Brown, P. (1968), “An empirical evaluation of accounting income numbers”, Journal of Accounting Research, Vol. 6, pp. 159-178.

Batten, J.A., Kinateder, H., Szilagyi, P. and Wagner, N. (2018), “Addressing COP21 using a Stock and Oil Market Integration Index”, Energy Policy, Vol 116, pp. 127-136.

Basak, S. and Pavlova, A. (2016), "A model of financialization of commodities", The Journal of Finance, Vol. 71 No. 4, pp. 1511-1556.

Böhringer, C., Hoffmann, T., Lange, A., Löschel, A. and Moslener, U. (2005), "Assessing emissions regulation in Europe: An interactive simulation approach", The Energy Journal, Vol. 26: pp. 1-22.

Bollerslev, T. (1998), “Generalized autoregressive conditional heteroscedasticity”, Journal of Econometrics, Vol. 31, pp. 307-327.

Bovenberg, L., Goulder, L.H. and Gurney, D.J. (2005), "Efficiency costs of meeting industry distributional constraints under environmental permits and taxes", RAND Journal of Economics, Vol. 36, pp. 951-971. 
Buchner, B., Carraro, C. and Ellerman, A.D. (2006), "The allocation of European Union allowances: Lessons, unifying themes and general principles”, FEEM Working Paper 116, 2006, Milan. SSRN Electronic Journal 31(1).

Bushnell, J.B., Chong, H. and Mansur, E.T. (2013), "Profiting from Regulation: Evidence from the European Carbon Market", American Economic Journal: Economic Policy, Vol. 5, pp. 78-106.

Clarke, R.G. (1980), "The effect of fuel adjustment clauses on the systematic risk and market values of electric utilities", Journal of Finance, Vol. 35, pp. 347-358.

Ellerman, A.D. and Buchner, B. (2008). "Over-allocation or abatement? A preliminary analysis of the EU ETS based on the 2005-06 emissions data", Environmental and Resource Economics, Vol. 41 No. 2, pp. 267-287.

European Commission, EU ETS handbook (2015).

Fama, E.F. (1991), “Efficient capital markets: II”, Journal of Finance, Vol. 46, pp. 1575-1617.

Handika, R,. and Putra, S., (2017), "Commodities returns' volatility in financialization era", Studies in Economics and Finance, Vol. 34 Issue: 3, pp.344-362

Jong, T., Couwenberg, O. and Woerdman, E. (2014), "Does EU Emissions Trading Bite? An Event Study”, Energy Policy, Vol. 69, pp. 510.519.

Kettner, C., Köppl, A., Schleicher, S.P. and Thenius, G. (2008), "Stringency and distribution in the EU Emissions Trading Scheme - The 2005 evidence”, Climate Policy, Vol. 8, pp. 41-61.

Koch, N., and Bassen, A. (2013), "Valuing the Carbon Exposure of European Utilities. The Role of Fuel Mix, Permit Allocation and Replacement Investments", Energy Economics, Vol. 36, pp. 431443.

Murphy, F. and McDonnell, K. (2017), "Investigation of the potential impact of the Paris Agreement on national mitigation policies and the risk of carbon leakage; an analysis of the Irish bioenergy industry", Energy Policy, Vol. 104, pp. 80-88.

Nasreen, S., and Anwar, S., (2015), "The impact of economic and financial development on environmental degradation: An empirical assessment of EKC hypothesis", Studies in Economics and Finance, Vol. 32 Issue: 4, pp.485-502.

Neuhoff, K., Keats Martinez, K. and Sato, M. (2006), "Allocation, incentives and distortions: impacts of the EU ETS Emissions Allowance allocations to the electricity sector", Climate Policy, Vol. 6, pp. 73-91.

Norton, S.W. (1985), "Regulation and systematic risk: the case of electric utilities", Journal of Law and Economics, Vol. 28, pp. 671-686.

Oberndorfer, U. (2009), "EU Emission Allowances and the Stock Market: Evidence from the Electricity Industry", Ecological Economics, Vol. 68, pp. 1116-1129.

Oestriech, A.M. and Tsiakas, I. (2015), "Carbon emissions and stock return: evidence from the EU emission trading scheme", Journal of banking and Finance, Vol. 58, pp. 294-308.

Sijm, J.P.M., Neuhoff, K. and Chen, Y. (2006), " $\mathrm{CO}_{2}$ Cost Pass-Through and Windfall Profits in the Power Sector”, Climate Policy, Vol. 6, pp. 49-72.

Smale, R., Hartley, Hepburn, M.C, Ward, J. and Grubb, M. (2006), "The Impact of $\mathrm{CO}_{2}$ Emissions Trading on Firm Profits and Market Prices", Climate Policy, Vol. 6, pp. 29-46. 
Stigler, G.J. and Friedland, C. (1962), "What can regulators regulate? The case of electricity", Journal of Law and Economics, Vol. 5, pp. 1-16.

Veith, S., Werner, J. and Zimmermann, J. (2009), "Capital Market Response to Emission Rights Returns: Evidence from the European Power Sector”, Energy Economics, Vol. 31, pp. 605-613.

Zimmermann, J, Veith, S. (2007), "Die Erfassung von CO2-Emissionsrechten in der wertmäßigen und ökologischen Kostenrechnung", Zeitschrift für Controlling und Management, Vol. 51, pp. 355364. 
Table 1: Description of variables

\begin{tabular}{|c|c|c|}
\hline Variable & Symbol & Description \\
\hline Stoxx return & $\mathrm{RM}$ & is the natural logarithm of the daily Stoxx 50 return, a proxy for market return \\
\hline Portfolio return & Portfolio return & is the weighted average of daily logged returns of the 16 firms included \\
\hline EUA return & EUA & is the natural logarithm of the daily emission allowance return \\
\hline Stock return & Stock & is the natural logarithm of the daily returns of the each energy firm \\
\hline Stoxx standard deviation & RMstd & is the standard deviation of the daily Stoxx returns \\
\hline EUA standard deviation & EUAstd & is the standard deviation of the daily allowance returns \\
\hline EUA squared returns & EUAsqrd & is the squared allowance returns to check for nonlinearity \\
\hline Portfolio variance & Portfolio variance & is the variance of the daily portfolio return \\
\hline Primary Energy Input & PEI & a categorical variable representing the principle energy input which is classified as fossil, renewable, and nuclear \\
\hline Share of renewable & $\%$ RES & is the logged share of renewable energy in the firm's power generation \\
\hline More renewable & MoreRES & a binary variable which takes a value of 1 for firms with share renewable above the average and 0 otherwise \\
\hline Carbon intensity & $\mathrm{CI}$ & is the logged value of the carbon emissions per each KWh generated \\
\hline Less carbon intensity & LessCI & a binary variable which takes a value of 1 for firms with $\mathrm{CI}$ below the median and 0 otherwise \\
\hline Aggregate & Aggregate & is the full dataset including all trading phases from $4 / 10 / 2005$ to $30 / 12 / 2016$ \\
\hline Phase 1 & Phase 1 & is the first trading phase of emission allowance for the period from 2005 to 2007 \\
\hline Phase 2 & Phase 2 & is the second trading phase of emission allowance from 2008 to 2012 \\
\hline Phase 3 & Phase 3 & is the third trading phase of emission allowance, 2013 to 2020 \\
\hline
\end{tabular}




\begin{tabular}{|c|c|c|c|c|c|c|c|c|c|c|c|c|}
\hline \multirow{2}{*}{$\#$} & \multirow{2}{*}{ Company } & \multirow{2}{*}{ Country } & \multicolumn{3}{|c|}{ Average daily return } & \multirow{2}{*}{$\begin{array}{c}\text { Generation } \\
\text { TWh } \\
\end{array}$} & \multirow{2}{*}{$\begin{array}{l}\text { Revenues } \\
\text { EUR bn }\end{array}$} & \multirow{2}{*}{$\begin{array}{c}\text { Profits } \\
\text { EUR mn }\end{array}$} & \multirow{2}{*}{$\begin{array}{c}\mathrm{CO} 2 \text { emission } \\
\mathrm{Mt}\end{array}$} & \multirow{2}{*}{$\begin{array}{c}\text { Carbon intensity } \\
\mathrm{CO} 2, \mathrm{~g} / \mathrm{kwh}\end{array}$} & \multirow{2}{*}{$\begin{array}{c}\text { Renewables } \\
\% \text { RES }\end{array}$} & \multirow{2}{*}{$\begin{array}{c}\text { Main } \\
\text { energy inpu }\end{array}$} \\
\hline & & & Phase1 & Phase2 & Phase3 & & & & & & & \\
\hline 1 & EDF & France & $0.19 \%$ & $-0.11 \%$ & $-0.02 \%$ & 619 & 75 & 1187 & 59 & 95 & 14 & Nuclear \\
\hline 2 & ENGIE & France & $0.08 \%$ & $-0.04 \%$ & $0.01 \%$ & 333 & 70 & -4617 & 133 & 445 & 23 & Fossil \\
\hline 3 & RWE & Germany & $0.10 \%$ & $-0.07 \%$ & $-0.07 \%$ & 284 & 49 & -170 & 151 & 708 & 7 & Fossil \\
\hline 4 & ENEL & Italy & $0.03 \%$ & $-0.04 \%$ & $0.04 \%$ & 213 & 76 & 2196 & 120 & 409 & 33 & Fossil \\
\hline 5 & E.ON & Germany & $0.12 \%$ & $-0.07 \%$ & $-0.06 \%$ & 189 & 116 & -6999 & 77 & 400 & 14 & Fossil \\
\hline 6 & IBERDROLA & Spain & $0.13 \%$ & $-0.03 \%$ & $0.05 \%$ & 137 & 31 & 2422 & 32 & 225 & 36 & Fossil \\
\hline 7 & CENRTICA & UK & $0.08 \%$ & $0.02 \%$ & $-0.03 \%$ & 22 & 39 & -1029 & 4 & 117 & 4 & Nuclear \\
\hline 8 & ENBW & Germany & $0.05 \%$ & $-0.04 \%$ & $-0.03 \%$ & 56 & 21 & 125 & 17 & 330 & 17 & Nuclear \\
\hline 9 & EDISON & Italy & $0.02 \%$ & $-0.05 \%$ & $0.00 \%$ & 18 & 11 & -980 & 6 & 319 & 25 & Fossil \\
\hline 10 & FORTUM & Finland & $0.14 \%$ & $-0.03 \%$ & $0.02 \%$ & 76 & 3 & -228 & 19 & 166 & 16 & Fossil \\
\hline 11 & EDP & Portogal & $0.12 \%$ & $-0.03 \%$ & $0.03 \%$ & 64 & 16 & 913 & 25 & 391 & 57 & Renewable \\
\hline 12 & FENOSA & Spain & $0.10 \%$ & $-0.06 \%$ & $0.04 \%$ & 50 & 26 & 1504 & 22 & 445 & 18 & Fossil \\
\hline 13 & VERBUND & Austria & $0.11 \%$ & $-0.05 \%$ & $-0.01 \%$ & 31 & 3 & 208 & 2 & 55 & 92 & Renewable \\
\hline 14 & CEZ & Czech & $0.14 \%$ & $-0.03 \%$ & $-0.04 \%$ & 54 & 8 & 760 & 29 & 471 & 7 & Nuclear \\
\hline 15 & PPC & Greece & $0.14 \%$ & $-0.07 \%$ & $0.01 \%$ & 34 & 6 & -107 & 34 & 1010 & 20 & Fossil \\
\hline 16 & SSE & UK & $0.09 \%$ & $0.00 \%$ & $0.02 \%$ & 28 & 44 & 748 & 13 & 474 & 33 & Fossil \\
\hline
\end{tabular}

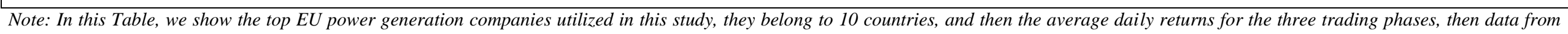
power generation to the end are a glimpse of firms' revenues and energy activity on 2015. 
Table 3: Panel descriptive statistics

\begin{tabular}{|c|c|c|c|c|c|c|}
\hline Period & Variable & Obs & Mean & STD & Min & Max \\
\hline \multirow{3}{*}{ Aggregate } & EUA & 45792 & 0.0001 & 0.032 & -0.330 & 0.470 \\
\hline & RM & 45792 & 0.0001 & 0.014 & -0.086 & 0.110 \\
\hline & Stock & 45758 & 0.0000 & 0.020 & -0.220 & 0.250 \\
\hline \multirow{3}{*}{ Phase 1} & EUA & 9120 & 0.0005 & 0.028 & -0.210 & 0.220 \\
\hline & RM & 9120 & 0.0004 & 0.009 & -0.330 & 0.029 \\
\hline & Stock & 9086 & 0.0010 & 0.016 & -0.130 & 0.160 \\
\hline \multirow{3}{*}{ Phase 2} & EUA & 20384 & -0.0005 & 0.030 & -0.290 & 0.460 \\
\hline & $\mathrm{RM}$ & 20384 & -0.0002 & 0.018 & -0.078 & 0.110 \\
\hline & Stock & 20384 & -0.0004 & 0.022 & -0.220 & 0.250 \\
\hline \multirow{3}{*}{ Phase 3} & EUA & 16256 & 0.0006 & 0.036 & -0.330 & 0.220 \\
\hline & $\mathrm{RM}$ & 16256 & 0.0002 & 0.012 & -0.086 & 0.047 \\
\hline & Stock & 16256 & 0.0000 & 0.019 & -0.210 & 0.170 \\
\hline
\end{tabular}

Note: In the Table, we show the descriptive statistics for the panel data as aggregate and separate phases. EUA, portfolio, and Stock are the logged daily returns of Emission allowance, single firms, and the financial index Stoxx50 respectively.

Table 4: Portfolio descriptive statistics

\begin{tabular}{|cllllllllll|}
\hline Period & Variable & Obs & Mean & STD & Min & Max & Phillip-Perron & Z(rho) & ADF & Z(t) \\
\hline \multirow{3}{*}{ Aggregate } & EUA & 2862 & -0.0004 & 0.032 & -0.410 & 0.380 & -14.10 & -2122 & -2.86 & -45.6 \\
& Portfolio & 2862 & -0.0001 & 0.011 & -0.077 & 0.106 & -14.10 & -2047 & -2.86 & -45.0 \\
& RM & 2862 & 0.0000 & 0.014 & -0.090 & 0.104 & -14.10 & -2282 & -2.86 & -50.0 \\
\hline \multirow{2}{*}{ Phase 1 } & EUA & 570 & 0.0001 & 0.028 & -0.230 & 0.200 & -14.00 & -369 & -2.87 & -17.6 \\
& Portfolio & 570 & 0.0009 & 0.007 & -0.054 & 0.025 & -14.00 & -435 & -2.87 & -19.9 \\
& RM & 570 & 0.0004 & 0.009 & -0.034 & 0.028 & -14.00 & -486 & -2.87 & -22.0 \\
\hline \multirow{2}{*}{ Phase 2 } & EUA & 1275 & -0.0010 & 0.030 & -0.340 & 0.380 & -14.10 & -1066 & -2.86 & -34.4 \\
& Portfolio & 1275 & -0.0006 & 0.013 & -0.076 & 0.105 & -14.10 & -868 & -2.86 & -30.3 \\
& RM & 1275 & -0.0004 & 0.018 & -0.082 & 0.104 & -14.10 & -997 & -2.86 & -33.8 \\
\hline \multirow{2}{*}{ Phase 3 } & EUA & 1017 & 0.0000 & 0.036 & -0.410 & 0.200 & -14.10 & -697 & -2.86 & -25.3 \\
& Portfolio & 1017 & -0.0001 & 0.010 & -0.077 & 0.036 & -14.10 & -810 & -2.86 & -27.4 \\
& RM & 1017 & 0.0002 & 0.012 & -0.090 & 0.046 & -14.10 & -865 & -2.86 & -29.7 \\
\hline
\end{tabular}

Note: In the Table, we show the descriptive statistics for the portfolio as aggregate and for each single phase, additionally we show the tests of the existence of a unit root in the time series (Phillip-Perron and the Augmented Dickey-Fuller (ADF)). EUA, portfolio, and $R M$ are the logged daily returns of Emission allowance, portfolio of firms, and the financial index Stoxx50 respectively. 
Accepted in “Studies in Economics and Finance”, Emerald publishing, DOI (10.1108/SEF-02-2018-0058)

Table 5: Aggregate panel regression results (daily observations from October 2005 to December 2016)

\begin{tabular}{|c|c|c|c|c|c|c|c|c|c|c|}
\hline \multirow{3}{*}{$\begin{array}{l}\text { Panel aggregate } \\
\text { Dependent variable } \\
\text { Stock return } \\
\end{array}$} & Model 1 & Model 2 & Model 3 & Model 4 & Model 5 & Model 6 & Model 7 & Model 8 & \multirow{3}{*}{$\begin{array}{l}\text { Model } 9 \\
\text { Fixed effect } \\
\text { Firm group } \\
\end{array}$} & \multirow{3}{*}{$\begin{array}{l}\quad \text { Model } 10 \\
\text { Random effect } \\
\text { GLS }\end{array}$} \\
\hline & \multicolumn{8}{|c|}{ OLS with firm and country fixed effects } & & \\
\hline & No FE & Country & Firm & PEI & $\%$ RES & MoreRES & $\mathrm{CI}$ & LessCI & & \\
\hline \multirow[t]{2}{*}{$\mathrm{RM}$} & $0.61 * * *$ & $0.61^{* * *}$ & $0.61^{* * *}$ & $0.61^{* * *}$ & $0.61^{* * *}$ & $0.61^{* * *}$ & $0.61^{* * *}$ & $0.61 * * *$ & $0.61 * * *$ & $0.61 * * *$ \\
\hline & 103.9 & 103.9 & 103.9 & 103.9 & 103.9 & 103.9 & 103.9 & 103.9 & 103.9 & 103.9 \\
\hline \multirow[t]{2}{*}{ EUA } & $0.016^{* * *}$ & $0.016^{* * *}$ & $0.016^{* * *}$ & $0.016^{* * *}$ & $0.016^{* * *}$ & $0.016^{* * *}$ & $0.016^{* * *}$ & $0.016^{* * *}$ & $0.016^{* * *}$ & $0.016^{* * * *}$ \\
\hline & 5.83 & 5.83 & 5.83 & 5.83 & 5.83 & 5.83 & 5.83 & 5.83 & 5.83 & 5.83 \\
\hline \multirow[t]{2}{*}{$\%$ RES } & & & & & 0.00007 & & & & & \\
\hline & & & & & 0.62 & & & & & \\
\hline \multirow[t]{2}{*}{ More RES } & & & & & & -0.0002 & & & & \\
\hline & & & & & & -1.2 & & & & \\
\hline \multirow[t]{2}{*}{$\mathrm{CI}$} & & & & & & & -0.00003 & & & \\
\hline & & & & & & & -0.23 & & & \\
\hline \multirow[t]{2}{*}{ Less CI } & & & & & & & & 0.00007 & & \\
\hline & & & & & & & & 0.41 & & \\
\hline \multirow[t]{2}{*}{ Constant } & -0.00006 & -0.00007 & 0.000 & -0.00007 & 0.00005 & 0.00009 & 0.00009 & -0.00009 & -0.00006 & -0.00006 \\
\hline & -0.73 & -0.2 & -0.03 & -0.2 & 0.25 & 0.59 & 0.14 & -0.8 & -0.73 & -0.73 \\
\hline Observations & 45758 & 45758 & 45758 & 45758 & 45758 & 45758 & 45758 & 45758 & 45758 & 45758 \\
\hline $\mathrm{R}$-squared & 0.1981 & 0.1982 & 0.1982 & 0.1982 & 0.1982 & 0.1982 & 0.1982 & 0.1982 & & \\
\hline Critical value & 0.000 & 0.000 & 0.000 & 0.000 & 0.000 & 0.000 & 0.000 & 0.000 & 0.000 & 0.000 \\
\hline Root MSE & 0.0183 & 0.0183 & 0.0183 & 0.0183 & 0.0183 & 0.0183 & 0.0181 & 0.0183 & & \\
\hline Country effect & No & Yes & No & No & No & No & No & No & & \\
\hline Firm effect & No & No & Yes & No & No & No & No & No & & \\
\hline PEI & No & No & No & Yes & No & No & No & No & & \\
\hline no. Of firms & 16 & 16 & 16 & 16 & 16 & 16 & 16 & 16 & & \\
\hline no. Countries & 10 & 10 & 10 & 10 & 10 & 10 & 10 & 10 & & \\
\hline Rho & & & & & & & & & 0.0001 & 0.000 \\
\hline
\end{tabular}

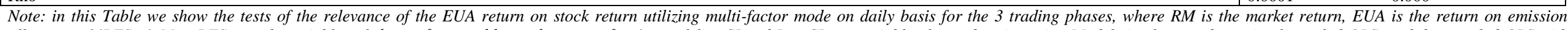

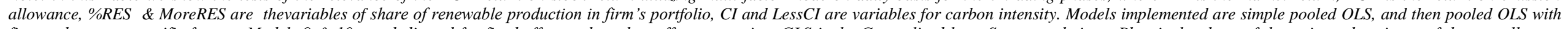

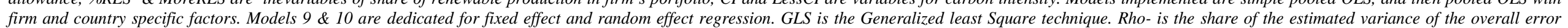

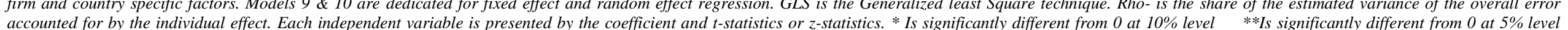
$* * *$ Is significantly different from 0 at $1 \%$ level. 
Accepted in “Studies in Economics and Finance”, Emerald publishing, DOI (10.1108/SEF-02-2018-0058)

Table 6: Phase 1 panel regression results (daily observations from October 2005 to December 2007)

\begin{tabular}{|c|c|c|c|c|c|c|c|c|c|c|}
\hline \multirow{3}{*}{$\begin{array}{l}\text { Panel phase I } \\
\text { Dependent variable } \\
\text { Stock return } \\
\end{array}$} & Model 1 & Model 2 & Model 3 & Model 4 & Model 5 & Model 6 & Model 7 & Model 8 & Model 9 & Model 10 \\
\hline & \multicolumn{8}{|c|}{ OLS with firm and country fixed effects } & \multirow{2}{*}{$\begin{array}{l}\text { Fixed effect } \\
\text { Firm group }\end{array}$} & \multirow{2}{*}{$\begin{array}{l}\text { Random effect } \\
\text { GLS }\end{array}$} \\
\hline & No FE & Country & Firm & PEI & $\%$ RES & MoreRES & $\mathrm{CI}$ & LessCI & & \\
\hline \multirow[t]{2}{*}{ RM } & $0.56^{* * *}$ & $0.56^{* * *}$ & $0.56^{* * *}$ & $0.56^{* * *}$ & $0.56^{* * *}$ & $0.56^{* * *}$ & $0.56^{* * *}$ & $0.56 * * *$ & $0.56 * * *$ & $0.56 * * *$ \\
\hline & 32.5 & 32.5 & 32.5 & 32.5 & 32.5 & 32.5 & 32.5 & 32.5 & 32.4 & 32.5 \\
\hline \multirow[t]{2}{*}{ EUA } & $0.024 * * *$ & $0.024 * * *$ & $0.024 * * *$ & $0.024 * * *$ & $0.024 * * *$ & $0.024 * * *$ & $0.024 * * *$ & $0.024 * * *$ & $0.024 * * *$ & $0.024 * * *$ \\
\hline & 4.13 & 4.13 & 4.13 & 4.13 & 4.13 & 4.13 & 4.13 & 4.13 & 4.13 & 4.13 \\
\hline \multirow[t]{2}{*}{$\%$ RES } & & & & & -0.00006 & & & & & \\
\hline & & & & & -0.27 & & & & & \\
\hline \multirow[t]{2}{*}{ More RES } & & & & & & -0.00008 & & & & \\
\hline & & & & & & -0.23 & & & & \\
\hline \multirow[t]{2}{*}{ CI } & & & & & & & -0.0001 & & & \\
\hline & & & & & & & -0.42 & & & \\
\hline \multirow[t]{2}{*}{ Less CI } & & & & & & & & 0.00002 & & \\
\hline & & & & & & & & 0.06 & & \\
\hline \multirow[t]{2}{*}{ Constant } & $0.0007 * * *$ & $0.0008^{* * *}$ & $0.0012 *$ & $0.0007 * * *$ & $0.0007^{*}$ & $0.0008^{* * *}$ & 0.0013 & $0.0007^{* * * *}$ & $0.0007^{* * *} *$ & $0.0007^{* * *}$ \\
\hline & 4.56 & 1.31 & 1.8 & 3.54 & 1.71 & 3.91 & 1.00 & 3.19 & 4.56 & 4.56 \\
\hline Observations & 9086 & 9086 & 9086 & 9086 & 9086 & 9086 & 9086 & 9086 & 9086 & 9086 \\
\hline R-squared & 0.105 & 0.105 & 0.106 & 0.105 & 0.105 & 0.105 & 0.105 & 0.105 & & \\
\hline Critical value & 0.000 & 0.000 & 0.000 & 0.000 & 0.000 & 0.000 & 0.000 & 0.000 & 0.000 & 0.000 \\
\hline Root MSE & 0.0155 & 0.0155 & 0.0155 & 0.0155 & 0.0155 & 0.0155 & 0.0155 & 0.0155 & & \\
\hline Country effect & No & Yes & No & No & No & No & No & No & & \\
\hline Firm effect & No & No & Yes & No & No & No & No & No & & \\
\hline PEI & No & No & No & Yes & No & No & No & No & & \\
\hline Rho & & & & & & & & & 0.0008 & 0.000 \\
\hline
\end{tabular}

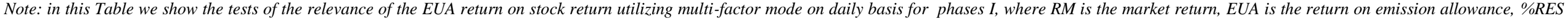



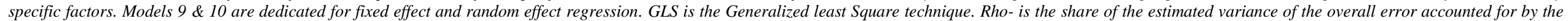

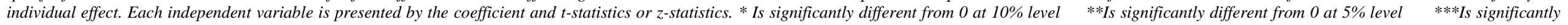
different from 0 at $1 \%$ level. 
Table 7: Phase 2 panel regression results (daily observations from January 2008 to December 2012)

\begin{tabular}{|c|c|c|c|c|c|c|c|c|c|c|}
\hline Panel phase II & Model 1 & Model 2 & Model 3 & Model 4 & Model 5 & Model 6 & Model 7 & Model 8 & Model 9 & Model 10 \\
\hline \multirow{2}{*}{$\begin{array}{l}\text { Dependent variable } \\
\text { Stock return }\end{array}$} & \multicolumn{8}{|c|}{ OLS with firm and country fixed effects } & \multirow{2}{*}{\begin{tabular}{|l} 
Fixed effect \\
Firm group \\
\end{tabular}} & \multirow{2}{*}{$\begin{array}{l}\text { Random effect } \\
\text { GLS }\end{array}$} \\
\hline & No FE & Country & Firm & PEI & $\%$ RES & MoreRES & $\mathrm{CI}$ & LessCI & & \\
\hline \multirow[t]{2}{*}{ RM } & $0.596^{* * * *}$ & $0.596^{* * * *}$ & $0.596 * * *$ & $0.596 * * *$ & $0.596 * * *$ & $0.596 * * *$ & $0.596^{* * * *}$ & $0.596^{* * * *}$ & $0.596 * * *$ & $0.596 * * *$ \\
\hline & 74.6 & 74.6 & 74.6 & 74.6 & 74.6 & 74.6 & 74.6 & 74.6 & 74.6 & 74.6 \\
\hline \multirow[t]{2}{*}{ EUA } & $0.011 * *$ & $0.011 * *$ & $0.011^{* *}$ & $0.011 * *$ & $0.011 * *$ & $0.011 * *$ & $0.011 * *$ & $0.011 * *$ & $0.011 * *$ & $0.011 * *$ \\
\hline & 2.26 & 2.26 & 2.26 & 2.26 & 2.26 & 2.26 & 2.26 & 2.26 & 2.26 & 2.26 \\
\hline \multirow[t]{2}{*}{$\%$ RES } & & & & & -0.00002 & & & & & \\
\hline & & & & & -0.13 & & & & & \\
\hline \multirow[t]{2}{*}{ More RES } & & & & & & 0.0002 & & & & \\
\hline & & & & & & 0.65 & & & & \\
\hline \multirow[t]{2}{*}{$\mathrm{CI}$} & & & & & & & -0.00002 & & & \\
\hline & & & & & & & -0.1 & & & \\
\hline \multirow[t]{2}{*}{ Less CI } & & & & & & & & 0.00007 & & \\
\hline & & & & & & & & 0.24 & & \\
\hline \multirow[t]{2}{*}{ Constant } & $(0.0003)^{* *}$ & -0.0003 & -0.0001 & $(0.0003)^{* *}$ & -0.0003 & $(0.0003)^{* *}$ & -0.0002 & $(0.0003)^{*}$ & $(0.0003)^{* *}$ & $(0.0003)^{* *}$ \\
\hline & -2.09 & -0.55 & -0.2 & & -1.01 & -2.1 & -0.17 & -1.65 & -2.09 & -2.09 \\
\hline Observations & 20384 & 20384 & 20384 & 20384 & 20384 & 20384 & 20384 & 20384 & & \\
\hline R-squared & 0.2278 & 0.2279 & 0.2278 & 0.2278 & 0.2278 & 0.2278 & 0.2278 & 0.2278 & & \\
\hline Critical value & 0.000 & 0.000 & 0.000 & 0.000 & 0.000 & 0.000 & 0.000 & 0.000 & 0.000 & 0.000 \\
\hline Root MSE & 0.02 & 0.02 & 0.02 & 0.02 & 0.02 & 0.02 & 0.02 & 0.02 & & \\
\hline Country effect & No & Yes & No & No & No & No & No & No & & \\
\hline Firm effect & No & No & Yes & No & No & No & No & No & & \\
\hline PEI & No & No & No & Yes & No & No & No & No & & \\
\hline Rho & & & & & & & & & 0.0002 & 0.000 \\
\hline
\end{tabular}


Table 8: Phase 3 panel regression results (daily observations from January 2013 to December 2016)

\begin{tabular}{|c|c|c|c|c|c|c|c|c|c|c|}
\hline Panel phase III & Model 1 & Model 2 & Model 3 & Model 4 & Model 5 & Model 6 & Model 7 & Model 8 & Model 9 & Model 10 \\
\hline Dependent variable & OLS & OLS-FE & OLS-FE & OLS-FE & OLS & OLS-FE & OLS & OLS-FE & $\mathrm{FE}$ & $\mathrm{RE}$ \\
\hline Stock return & No FE & Country & Firm & PEI & $\%$ RES & MoreRES & $\mathrm{CI}$ & LessCI & Firm group & GLS \\
\hline \multirow[t]{2}{*}{ RM } & $0.654 * * *$ & $0.654 * * *$ & $0.654 * * *$ & $0.654 * * *$ & $0.654 * * *$ & $0.654 * * *$ & $0.654 * * *$ & $0.654 * * *$ & $0.654 * * *$ & $0.654 * * *$ \\
\hline & 59.5 & 59.5 & 59.5 & 59.5 & 59.5 & 59.5 & 59.5 & 59.5 & 59.5 & 59.5 \\
\hline \multirow[t]{2}{*}{ EUA } & $0.017^{* *}$ & $0.017 * *$ & $0.017^{* *}$ & $0.017^{* *}$ & $0.017^{* *}$ & $0.017^{* *}$ & $0.017^{* *}$ & $0.017 * *$ & $0.017^{* *}$ & $0.017 * *$ \\
\hline & 4.4 & 4.4 & 4.4 & 4.4 & 4.4 & 4.4 & 4.4 & 4.4 & 4.4 & 4.4 \\
\hline \multirow[t]{2}{*}{$\%$ RES } & & & & & 0.0003 & & & & & \\
\hline & & & & & 1.42 & & & & & \\
\hline \multirow[t]{2}{*}{ More RES } & & & & & & 0.0004 & & & & \\
\hline & & & & & & 1.45 & & & & \\
\hline \multirow[t]{2}{*}{$\mathrm{CI}$} & & & & & & & 0.0000 & & & \\
\hline & & & & & & & -0.03 & & & \\
\hline \multirow[t]{2}{*}{ Less CI } & & & & & & & & 0.0001 & & \\
\hline & & & & & & & & 0.39 & & \\
\hline \multirow[t]{2}{*}{ Constant } & $(0.0002)^{*}$ & -0.0003 & -0.0006 & -0.0001 & 0.0001 & $(0.0004)^{* *}$ & -0.0002 & -0.0003 & $(0.0002)^{*}$ & $(0.0002)^{*}$ \\
\hline & -1.69 & -0.56 & -1.05 & -0.85 & 0.56 & -2.21 & -0.19 & -1.47 & -1.69 & -1.69 \\
\hline Observations & 16256 & 16256 & 16256 & 16256 & 16256 & 16256 & 16256 & 16256 & & \\
\hline $\mathrm{R}$-squared & 0.1835 & 0.1838 & 0.1838 & 0.1836 & 0.1836 & 0.1836 & 0.1835 & 0.1835 & & \\
\hline Critical value & 0.000 & 0.000 & 0.000 & 0.000 & 0.000 & 0.000 & 0.000 & 0.000 & & \\
\hline Root MSE & 0.017 & 0.017 & 0.017 & 0.017 & 0.017 & 0.017 & 0.017 & 0.017 & & \\
\hline Country effect & No & Yes & No & No & No & No & No & No & & \\
\hline Firm effect & No & No & Yes & No & No & No & No & No & & \\
\hline PEI & No & No & No & Yes & No & No & No & No & & \\
\hline Rho & 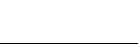 & 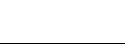 & & 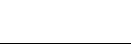 & &  & & 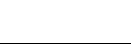 & 0.0004 & 0.000 \\
\hline
\end{tabular}


Table 9: Portfolio Return analysis

\begin{tabular}{|c|c|c|c|c|c|c|c|}
\hline Portfolio & Model 1 & Model 2 & Model 3 & Model 4 & Model 5 & Model 6 & Model 7 \\
\hline \multirow{2}{*}{$\begin{array}{l}\text { Dependent variable } \\
\text { Portfolio return }\end{array}$} & \multicolumn{2}{|c|}{ Aggregate } & \multicolumn{2}{|c|}{ Phase 1} & \multicolumn{2}{|c|}{ Phase 2} & Phase 3 \\
\hline & OLS & Robust & OLS & Prais & OLS & Prais & OLS \\
\hline \multirow[t]{2}{*}{ RM } & $0.62 * * *$ & $0.59^{* * *}$ & $0.56^{* * *}$ & $0.55^{* * *}$ & $0.61 * * *$ & $0.603 * * *$ & $0.67^{* * *}$ \\
\hline & 68.3 & 73.9 & 22.05 & 21.9 & 47.6 & 47.3 & 40.80 \\
\hline \multirow[t]{2}{*}{ EUA } & $0.017 * * *$ & $0.014 * * *$ & $0.023 * * *$ & $0.022 * * *$ & $0.014 *$ & $0.014 *$ & $0.017 * * *$ \\
\hline & 4.08 & 3.8 & 2.73 & 2.62 & 1.77 & 1.81 & 3.06 \\
\hline \multirow[t]{2}{*}{ Constant } & -0.0001 & -0.00003 & $.0007 * * *$ & $.0007^{* * *}$ & -0.0003 & -0.0003 & -0.0002 \\
\hline & -0.79 & -0.2 & 2.77 & 2.67 & -1.54 & -1.47 & -1.19 \\
\hline Observations & 2862 & 2862 & 570 & 570 & 1275 & 1275 & 1017 \\
\hline R-squared & 0.632 & & 0.463 & 0.462 & 0.660 & 0.658 & 0.629 \\
\hline Critical value & 0.000 & 0.000 & 0.000 & 0.000 & 0.000 & 0.000 & 0.000 \\
\hline Root MSE & 0.007 & & 0.0057 & 0.0057 & 0.0079 & 0.0079 & 0.0065 \\
\hline Durbin-Watson & 1.54 & & 1.42 & $1.54^{*}$ & 1.48 & $1.55^{*}$ & 1.71 \\
\hline Rho & & & & 0.067 & & 0.042 & \\
\hline
\end{tabular}

Note: in this Table we present the regression models of the portfolio for the three trading phases together and separately to test the return relationship, for each phase an OLS is applied in addition to the robust regression in case of heteroscedasticity and PraisWinsten regression in case of serial correlation. Durbin-Watson* is the transformed value after applying Prais-Winsten regression. Rho is the correlation of residuals. * Is significantly different from 0 at $10 \%$ level $\quad * *$ Is significantly different from 0 at $5 \%$ level $\quad * * * I s$ significantly different from 0 at $1 \%$ level.

Table 10: Portfolio robustness tests

\begin{tabular}{|c|c|c|c|c|c|c|}
\hline Portfolio & Model 1 & Model 2 & Portfolio & Model 3 & Model 4 & Model 5 \\
\hline $\begin{array}{l}\text { Dep. variable } \\
\text { Portfolio return }\end{array}$ & OLS & $\begin{array}{l}\text { ARMA } \\
(1,1) \\
\end{array}$ & $\begin{array}{l}\text { Dep. variable } \\
\text { Portfolio variance }\end{array}$ & $\begin{array}{r}\text { GARCH } \\
(1,1) \\
\end{array}$ & $\begin{array}{r}\text { GARCH } \\
(1,1) \\
\end{array}$ & $\begin{array}{r}\text { GARCH } \\
(1,1) \\
\end{array}$ \\
\hline $\mathrm{RM}$ & $\begin{array}{l}0.62 * * * \\
38.1\end{array}$ & $\begin{array}{l}0.62 * * * \\
105.6\end{array}$ & EUA & & $\begin{array}{l}0.046^{* * *} \\
10.9\end{array}$ & \\
\hline EUA & $\begin{array}{l}0.018 * * * \\
4.22\end{array}$ & $\begin{array}{l}0.016^{* * *} \\
4.08\end{array}$ & RMstd & & & $\begin{array}{l}0.065^{\text {*** }} \\
5.5\end{array}$ \\
\hline $\mathrm{AR}(1)$ & & $\begin{array}{l}(0.73)^{* * *} \\
-4.6\end{array}$ & EUAstd & & & $\begin{array}{l}-0.008 \\
-1.5\end{array}$ \\
\hline MA(1) & & $\begin{array}{l}0.76^{* * * *} \\
5.1\end{array}$ & $\mathrm{ARCH}(\mathrm{L} 1)$ & $\begin{array}{l}0.17^{* * *} \\
8.8\end{array}$ & $\begin{array}{l}0.17^{* * *} \\
8.6\end{array}$ & $\begin{array}{l}0.17^{* * *} \\
8.5\end{array}$ \\
\hline EUAsqrd & $\begin{array}{l}(0.11)^{* * *} \\
-2.8\end{array}$ & & GARCH (L1) & $\begin{array}{l}0.95^{* * *} \\
21.1\end{array}$ & $\begin{array}{l}0.96^{* * *} \\
19.7\end{array}$ & $\begin{array}{l}0.97^{* * *} \\
20.6\end{array}$ \\
\hline Observations & 2862 & 2862 & & 2862 & 2862 & 2861 \\
\hline Critical value & 0.000 & 0.000 & & 0.000 & 0.000 & 0.000 \\
\hline
\end{tabular}

Note: In this Table, we present the quadratic regression in model 1, in model 2 we show the ARMA model to take into account the serial correlation of returns, models $3,4 \& 5$ represent the GARCH models to test the volatility association between EUA variables and portfolio variance.

*Is significantly different from 0 at $10 \%$ level $\quad * *$ Is significantly different from 0 at $5 \%$ level $\quad * * *$ Is significantly different from 0 at $1 \%$ level. 